The 7 Aarhus Statements on Climate Change

This article has been downloaded from IOPscience. Please scroll down to see the full text article.

2009 IOP Conf. Ser.: Earth Environ. Sci. 8011002

(http://iopscience.iop.org/1755-1315/8/1/011002)

The Table of Contents and more related content is available

Download details:

IP Address: 130.226.205.4

The article was downloaded on 24/02/2010 at 09:07

Please note that terms and conditions apply. 


\title{
The 7 Aarhus Statements on Climate Change
}

By Professor dr.jur. Ellen Margrethe Basse', Professor Jens-Christian Svenning ${ }^{2}$, Professor Jørgen E Olesen, ${ }^{3}$, Professor Flemming Besenbacher, ${ }^{4}$, Professor Jeppe Lass $\phi e^{5}$, Associate Professor Marit-Solveig Seidenkrantz ${ }^{6}$ and Professor Lene Lange ${ }^{7}$

${ }^{1}$ Head of the Climate Panel and Secretariat, Aarhus University

${ }^{2}$ Department of Biological Sciences, Faculty of Science, Aarhus University

${ }^{3}$ Faculty of Agricultural Sciences, Aarhus University

${ }^{4}$ iNANO, Faculty of Science, Aarhus University

${ }^{5}$ Department of Curriculum Research, Danish School of Education, Aarhus University

${ }^{6}$ Centre for Past Climate Studies, Department of Earth Sciences, Faculty of Science, Aarhus University

${ }^{7}$ Department of Biotechnology, Chemistry and Environmental Engineering, Aalborg University

E-mail: emb@adm.au.dk

\begin{abstract}
More than 1,000 prominent representatives from science, industry, politics and NGOs were gathered in Aarhus on 5.-7. March 2009 for the international climate conference "Beyond Kyoto: Addressing the Challenges of Climate Change". Thematically, Beyond Kyoto was divided into seven areas of particular interest for understanding the effects of the projected future climate change and how the foreseen negative impacts can be counteracted by mitigation and adaptation measures. The themes were 'Climate policy: the role of law and economics' , 'Biodiversity and ecosystems', 'Agriculture and climate change', 'Nanotechnology solutions for a sustainable future', 'Citizens and society' and 'The Arctic'. The main responsible scientists for the seven conference themes and representatives from the think-tank CONCITO delivered "The 7 Aarhus Statements on Climate Change" as part of the closing session of the conference. The statements were also communicated to the Danish Government as well as to the press. This article is the product of the collective subsequent work of the seven theme responsibles and is a presentation of each theme statement in detail, emphasizing the current state of knowledge and how it may be used to minimize the expected negative impacts of future climate change.
\end{abstract}

The international climate conference "Beyond Kyoto: Addressing the Challenges of Climate Change" was part of the official preparations for the United Nations Framework Convention on Climate Change (UNFCCC) Conference of the Parties (COP15) to be held in Copenhagen from December $7^{\text {th }}$ to $18^{\text {th }}$ 2009. It was organised by Aarhus University in collaboration with many other expert institutions, authorities, and enterprises. The conference aimed specifically at creating dialogue and knowledge transfer between the sciences, industry, and civil society to portray and communicate the current knowledge base to political decision makers, and was very successful in doing this.

Thematically, Beyond Kyoto was divided into seven areas of particular interest for understanding the 
effects of future climate change and how the foreseen negative impacts can be counteracted by mitigation and adaptation measures (Table 1).

Theme 1

Climate policy:

the role of law

and economics

\section{Theme 2}

Biodiversity and

ecosystems

\section{Theme 3 \\ Agriculture and \\ climate change}

\section{Theme 4}

Nanotechnology

solutions for a

sustainable future

\section{Theme 5 \\ Citizens and society}

Theme 6

The Arctic

Theme 7

Integrated

Energy Solutions
This theme focused on how to design a regulatory architecture, including legislative and economic instruments, addressing environmental issues and competitive concerns.

The focus of this theme was on the importance of the climate-biodiversity relationship, not just in terms of the challenges and adaptation possibilities for nature conservation in the $21^{\text {st }}$ century, but also for the future climate itself, notably the scope for mitigation of greenhouse gas emissions by the management of tropical forests and other natural areas.

The theme was concerned with the impacts of climate change on agriculture and forestry, and how management can be adapted to the changing climatic conditions and improved to reduce greenhouse gas emissions.

Each of the five sessions in this theme consists of a mixture of talks on nanotechnology and renewable energy, hydrogen technology, solar energy, wind energy, as well as catalysis and biofuels.

This theme focused on what drives changes in the social practices and individual actions that causes global warming and how to promote a more sustainable development in terms of reducing GHG emissions.

The sessions in this theme focused on climatic changes and their consequences in the Arctic, integrating central aspects of other themes to synthetically address the climate change issue for a single geographical region.

Renewable energy and energy efficiency are an important part of sustainable solutions and elements for mitigation of climate change and were the main issues of this theme.

Table 1

Each theme was further divided into 2-5 sessions selectively focusing on important areas within each theme. The main responsible scientists for the seven conference themes and representatives from the think-tank CONCITO delivered "The 7 Aarhus Statements on Climate Change" as part of the closing session of the conference. The statements were also communicated to the Danish Government as well as the press. Subsequently, the statements have been presented on a number of occasions. Below, we present each theme in detail with respect to current status of knowledge and how this may be used to counter future problems caused by the projected changes in climate.

\section{Theme 1. Climate policy: the role of law and economics}

The focal point of Theme 1 was the importance of the legal, economic, and infrastructural instruments. The different perspectives and possible instruments regarding the post-Kyoto regime were among the 
issues covered by this theme (table 2). The first session focused on the legal challenges of climate change. Session 2 discussed the concept of investment under the post-Kyoto regime in both developing and developed countries. Session 3 focused on important aspects of governance of the energy sector - with a view to transforming this sector from a conventional to a renewable energy basis (focusing on institutions). Session 4 dealt with various aspects of regulatory systems and instruments, economic analysis and the impact of policy-based commitments. Finally, infrastructure and the management of smart growth was the central issue discussed during session 5.

\section{Session 1 Legal aspects of long-term cooperative action \\ Session 2 Investment and financial flows to address climate change}

Session 3 Making room for renewable energy in power systems

Session 4 Regulation, economic analysis and impact of policybased commitments

Session 5 Infrastructure and the management of growth

\section{Table 2}

The discussions during this theme resulted in a recommendation for the stronger involvement of all sectors in the decision-making as well as in the implementation of decisions. Climate change is one of the biggest challenges that have yet faced mankind - so we must all help to find the solutions. It was concluded that far greater efforts are needed to ensure the involvement of the private sector and civil society in climate solutions. Challenges in respect to climate change are above all one of leadership, co-ordination, and collective action.

The involvement of governments should lead to the establishment of new and stronger institutions as well as international law and regulations that ensure efficiency with regard to mitigation and adaptation as well as sustainable development. At the heart of the challenge is the need for institutions that provide coherent and credible signals about future risks and opportunities and to ensure that the institutional framework is sufficiently resilient to maintain its function over a very long term. The institutions must focus on the needs of the present without compromising the ability of future generations to meet their own needs [1]. The development of new policy instruments, including ecotaxes, cap-and-trade regimes and other market-based instruments, voluntary agreements, performance standards and informational devices such as labels, has grown as part of the climate policy. Most of the existing agreements and instruments are formulated in highly general and abstract terms. International regulations should be formulated in a way, which can be accepted and understood by the public. The lack of precise objectives is a major difficulty in measuring achievements. The need is not for less regulation, but for better regulation [2].

It is well known that participation of both the private sector and civil society at international, national, and local levels is crucial with respect to the effectiveness of the legal framework for climate-change mitigation and adaptation [3, 4, 5, 6]. The involvement of the civil society is crucial in both negotiating and implementing international treaties and protocols on climate issues. The regulatory design must ensure both human rights and the efficiency of global agreements. Public participation in 
decision-making legitimizes decisions, and, if properly employed, may also improve their quality.

The transformation into a non-carbon society faces many challenges, for instance with regard to financing facilities. In the post-Kyoto-regime the private sector is expected to be a much larger source of funding than the public sector, making it critical that policies promote the flow of such funding. Public funds are also important to catalyze the generation of private funds, but the private sector has to deliver the vast majority of the required investments in climate change mitigation and adaptation. Consequently, we need to ensure stronger incentives and to reduce the barriers for private investors in these fields. Hence, financial mechanisms and institutions should be framed to facilitate further private investments. Future financial mechanisms should as a minimum have clear and focused objectives that are implemented in a more strategic and holistic way. This action could be taken immediately. The UNFCCC established the legal framework as long ago as 1992.

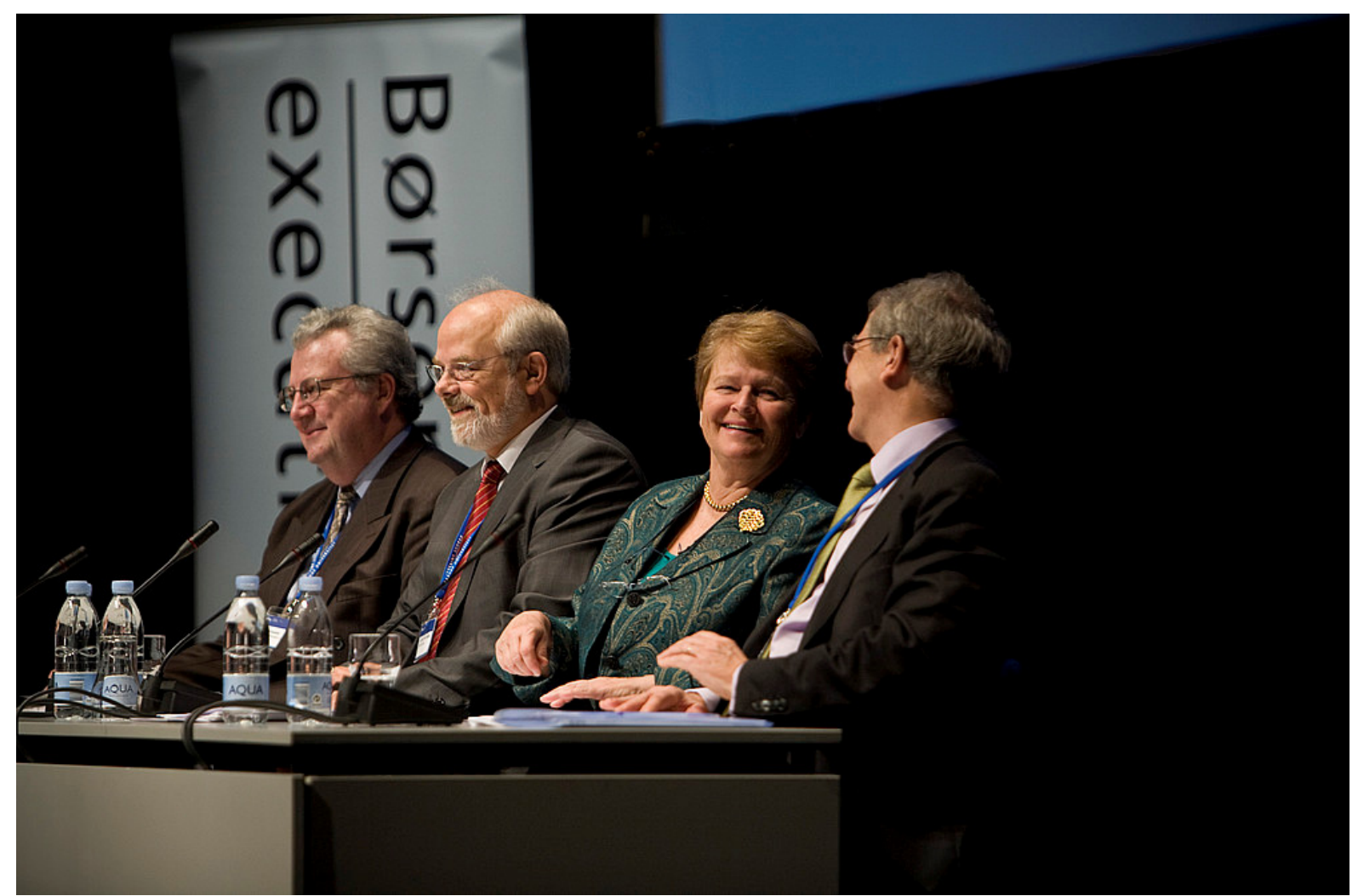

Figure 1. From left is John D. Hofmeister (Founder and CEO, Citizens for Affordable Energy), Lauritz B. Holm-Nielsen (Vice-chancellor, Aarhus University), Dr. Gro Harlem Brundtland (Special Envoy on Climate Change for United Nations Secretary-General Ban Ki-moon) and Sir David King (Professor, bbSmith School of Enterprise and the Environment) in a full up auditorium during the opening session at the Beyond Kyoto conference. Photo: Lars Kruse/AU-photo.

\section{Theme 2. Biodiversity and ecosystems}

Theme 2 focused on the importance of the climate-biodiversity relationship, not just for nature conservation in the $21^{\text {st }}$ century, but also for the future climate itself. During session 1 the participants discussed the scientific basis for predicting the impact of future climate change on biodiversity and ecosystem functioning. During session 2 the possibilities for mitigation of greenhouse gas emissions by the management of natural areas were discussed. The need for sustainable management of ecosystem services and biodiversity under climate change also was emphasized in session 3 . Session 4 dealt with the ways in which climate-driven changes in agriculture will affect natural ecosystems and 
biodiversity, focusing on the possibilities for efficient agricultural adaptation without imposing additional negative pressure on ecosystems and biodiversity. The possibilities for minimizing losses of biodiversity induced by climate change by the adaptive management of landscapes and seascapes were the focal point in session 5. Finally, during session 6 the talks focused on the role of the global environmental conventions, notably the Convention on Biological Diversity (CBD) in protecting biodiversity and ecosystems under climate change.

Session 1 The scientific basis for predicting the impacts of future climate change

Session 2 Mitigation by management of natural areas

Session $3 \quad$ Sustainable management of ecosystems and biodiversity

Session $4 \quad$ Theme 2 -3 jointly (theme 3: session 3):

Climate change and impacts of agriculture on ecosystems and biodiversity

Session $5 \quad$ Adaptive management of land-and seascapes

Session 6 The role of global environment conventions in protection of biodiversity and ecosystem in a phase of climate change

\section{Table 3}

The concluding statement on the biodiversity and ecosystems theme emphasized the need to include biodiversity as an integrated part of the general climate change mitigation and adaptation efforts.

Currently, biodiversity is under negative pressure from land-use, biological invasions, and pollution. As a result, numerous species are threatened with extinction; this is true, for example, for $25 \%$ of the roughly 5,500 mammal species in the world [7]. Over the next 100 years the changing climate will constitute an additional pressure, with potentially severe impacts $[8,9]$. Climate is already affecting ecosystems and biodiversity globally, causing changes in the functioning of ecosystems, species abundances, and species ranges [9]. With an increase in global mean temperature of just $>1.5-2.5^{\circ} \mathrm{C}$, $20-30 \%$ of the species studied may experience an increased risk of extinction [9].

Although major losses are unavoidable if climate change is not strongly curtailed beyond business-asusual expectations, the climate-change impact will depend greatly on interactions with other pressures, notably land-use $[8,9]$. Key adaptation strategies are described in the following two main points.

- One key adaptation strategy would involve decreasing other pressures on biodiversity (habitat loss etc.) to increase resilience to climate change [9]. It is therefore crucial that climate change mitigation and adaptation measures, especially in land-use (e.g. biofuel crops), are implemented in ways that alleviate rather than place additional negative pressure on biodiversity.

- A key facet of climate-change-integrated conservation planning is to actively improve the possibilities for the maintaining or re-establishing viable, broadly distributed, and genetically diverse populations in the face of climate change by a variety of means such as expanding 
reserve systems, designing reserve systems that are resilient to climate change, climate change-off-setting local management (controlled burning to reduce fuel loads etc.), captive breeding, assisted migration (translocation), engineering new habitats etc. [9. 10, 11, 12].

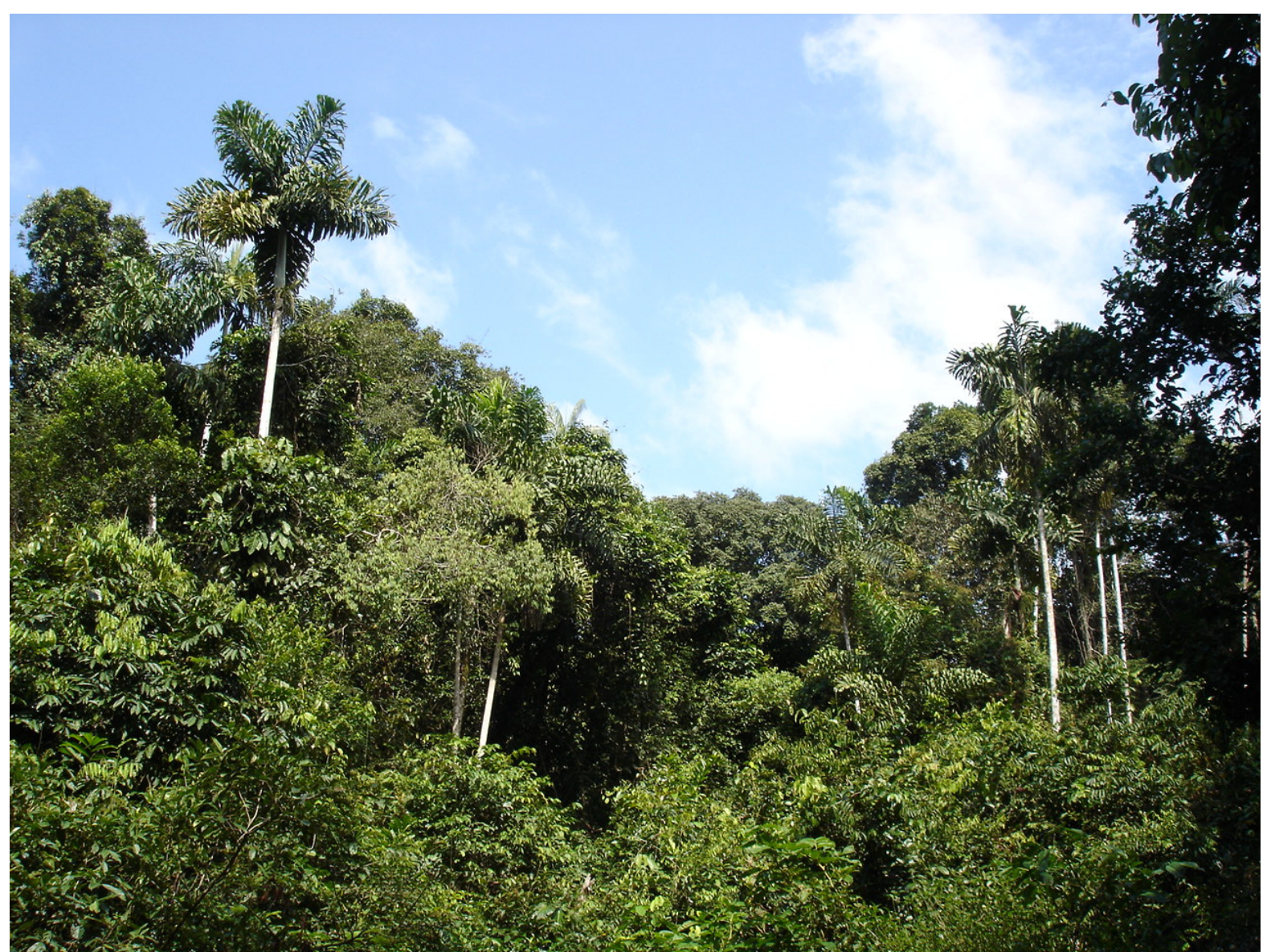

Figure 2. Theme 2 focused on the importance of the climate-biodiversity relationship, not just for nature conservation, but also for the future climate itself. Notably, forest conservation including Reduced Emissions from Deforestation and Degradation (REDD) represents a major and cost-effective climate change mitigation opportunity. One of the key points mentioned in the statement was that biodiversity needs to be an integrated part of the general climate change mitigation and adaptation efforts. Photo: Thea Kristiansen.

Biodiversity and in particular forests also constitute a major part of the solution to the climate change problem $[13,14]$. Notably, forest conservation including Reduced Emissions from Deforestation and Degradation (REDD) represents a major and cost-effective climate change mitigation opportunity [14]. Emissions from land-use change, especially tropical deforestation contribute about $20 \%$ of total anthropogenic greenhouse gas (GHG) emissions [9]. At the same time, forests including old-growth and tropical forests also constitute very important carbon sinks [15, 16, 17, 18]. Consequently, an important opportunity for climate change mitigation is the conservation of forests, notably carbon- and biodiversity-rich tropical forests $[9,19,20,21]$. By reducing pressure on tropical forests, deforestation and degradation is also likely to have direct benefits for biodiversity [22]. Afforestation and reforestation can also contribute importantly to carbon sequestration [9] and reduce pressure on forest biodiversity [23]. To realize this key opportunity for climate change mitigation it is absolutely crucial that economic structures that provide the incentives for forest conservation are implemented.

One of the key points mentioned in the statement was that biodiversity needs to be an integrated part 
of the general climate change mitigation and adaptation efforts. Climate-change adaptation and mitigation in other sectors may have positive, neutral, or negative impacts on biodiversity [23], and synergies could be promoted by formulating integrated policies cross-linking major UN conventions, notably the UNFCCC and the Convention on Biological Diversity [9].

\section{Theme 3. Agriculture and Climate Change}

Theme 3 focused on the contribution of agriculture to mitigating greenhouse gas emissions and, at the same time, the need for adapting agricultural practices to climate change to meet the increasing demands for food, feed, fibre, and fuel. The theme was therefore concerned with the impacts of climate change on agriculture and forestry, and how management can be adapted to the changing climatic conditions and improved to reduce greenhouse gas emissions and sequester carbon. The focus was on the effects of changes in both mean climate and inter-annual variability, and on different responses in different regions of the world (Table 4). These response differences are a key factor in the vulnerability of agricultural food production systems. They also mean that adapting agricultural production to changing conditions will take very different routes in various parts of the world, depending not only on soil and climatic conditions, but also on the capacity to adapt as determined by the economic, social, and technological status of a given region. The discussions during session 1 and session 2 were related to climate-change impacts on agriculture and forestry in developing countries and intensive agricultural systems in developed countries, respectively. In a global context, some resources are readily available to most countries; however, others are unevenly distributed given current available technologies. Session 3 primarily considered the ways in which climate-driven changes in agriculture will affect natural ecosystems and biodiversity, focusing on the possibilities for efficient agricultural adaptation without imposing additional negative pressure on ecosystems and biodiversity. Session 4 focused on the role of bioenergy and biofuels, which are both renewable energies that will play a key role in achieving a sustainable energy system, whilst session 5 focused on the possibilities for reducing agricultural GHG emissions.

$\begin{array}{ll}\text { Session } 1 & \text { Impacts and adaption in developing countries } \\ \text { Session } 2 & \text { Impacts and adaption in intensive agricultural systems } \\ \text { Session } 3 & \begin{array}{l}\text { Theme 2 }-3 \text { jointly (theme } 2: \text { session } 4): \\ \text { Climate change and impacts of agriculture on ecosystems and } \\ \text { biodiversity }\end{array}\end{array}$

Session $4 \quad$ The role of bioenergy and biofuels

Session $5 \quad$ Reducing agricultural GHG emissions

Table 4

The primary aim of agricultural mitigation is the reduction of greenhouse gas emissions (methane and nitrous oxide), and the increase of soil carbon storage [24]. Globally agriculture contributes to $\mathrm{CO}_{2}$ emissions by, e.g. deforestation, which can only be reduced if the productivity of existing agricultural land is improved through better crops and better soil and water management. Theme 3 recommended increasing agricultural productivity and reducing the use of water and land. An effective implementation of such a strategy urgently requires a substantial increase in research and innovation as well as in education and knowledge-transfer to farmers. 


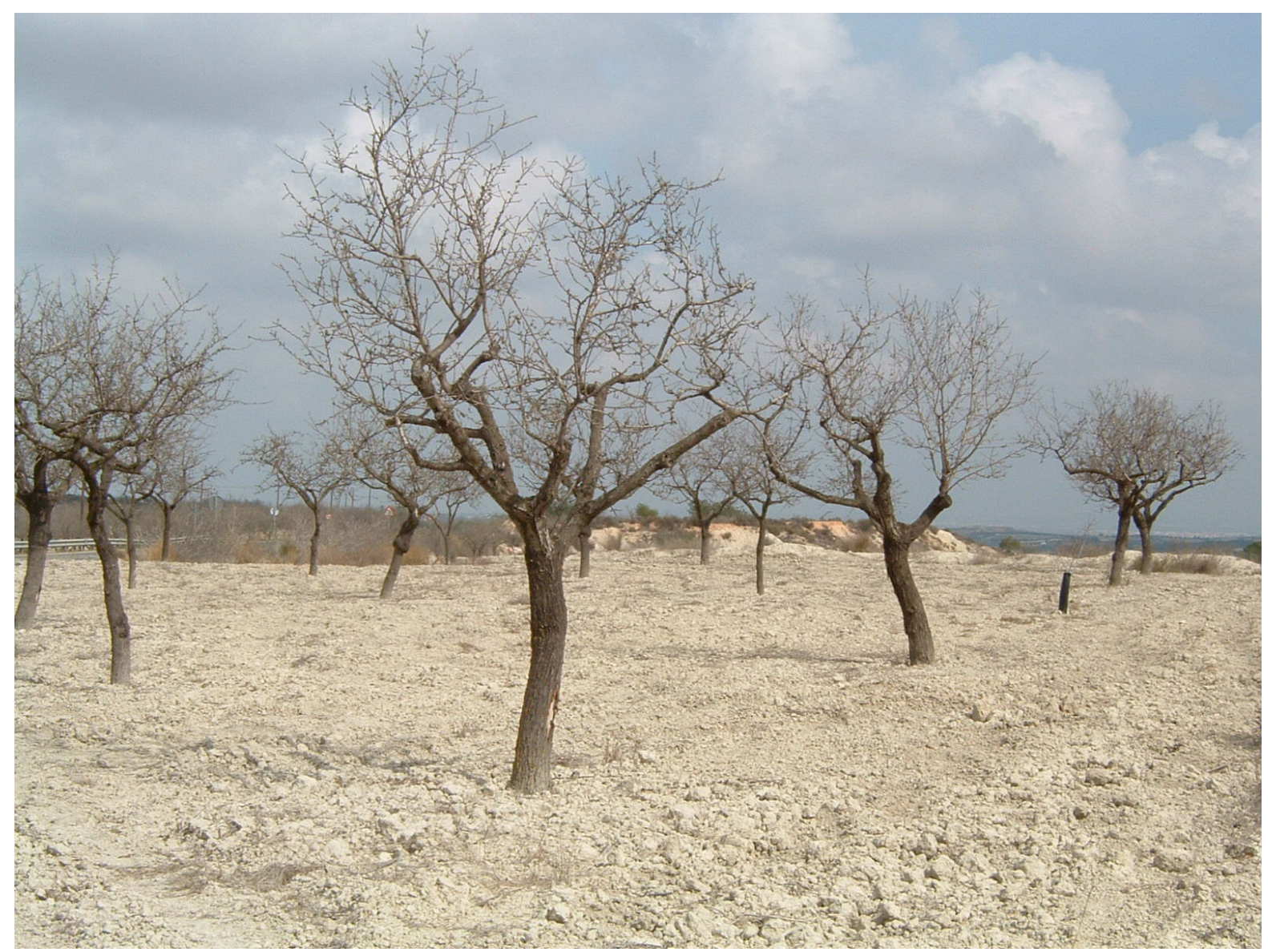

Figure 3. Droughts are projected to become a more frequent and longer lasting under climate change, and this will have severe impacts on food production and food security, in particular in developing countries. It may also compromise some of the ambitions for significantly expanding biofuel production due to lack of water for supporting the biomass production. Photo: Jorgen E. Olesen.

To reduce the dependency of society on fossil fuels, there is a high demand for increasing the use of bioenergy and bio-fuels [25]. These renewable energy sources are attracting more and more attention globally, not least because they have the potential to address concerns about climate change, the environment, energy security, and the opportunity to modernise energy services in developing countries. It was the opinion of the participants that this can only be achieved by developing new, highly productive bioenergy cropping systems that make use of land, which is not suitable for food and feed production, and which does not currently have high biodiversity and/or high carbon stocks. In addition, there is a need to better integrate ethical concerns regarding effects of increasing biofuel production on food prices and on biodiversity.

Adaptation in agriculture to increased climate variability involves increasing the resistance and resilience of production systems [26]. This can be done by improving soils, water use, crops, and cropping systems. There is a need to ensure that soils are managed to harvest and store rainwater more effectively. Irrigation water must be used more efficiently, and crops must be made more drought resistant through breeding programmes. In addition, cropping systems must be designed to conserve more water and provide better protection from the consequences of droughts, heat waves, and floods [9]. 


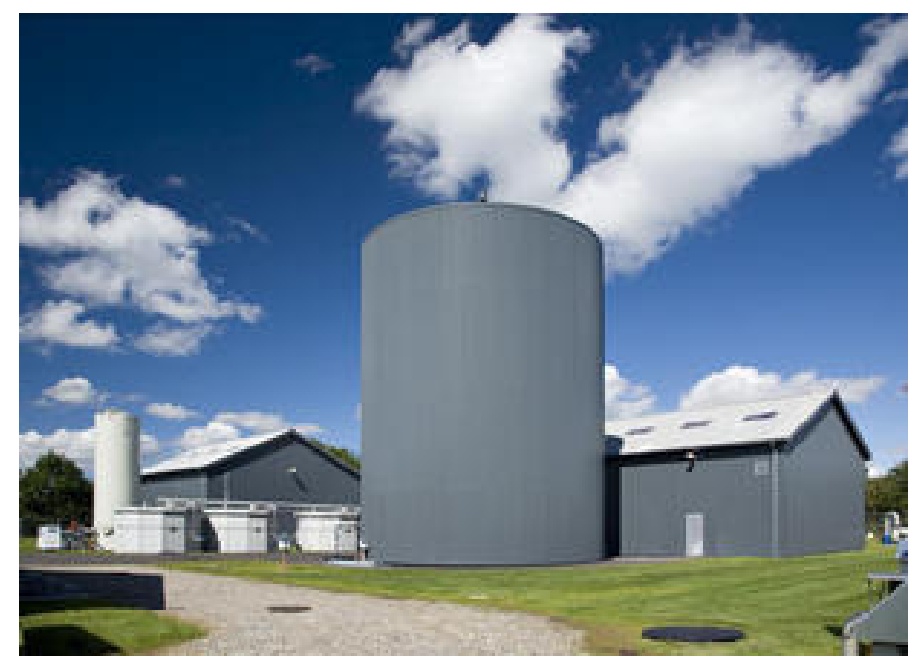

Figure 4. A picture of the worlds largest experimental biogas plant, situated at Research Centre Foulum, Aarhus University.

The greatest challenge facing agriculture during the $21^{\text {st }}$ century is probably how to feed the increasing not only an increasing population, but also an increasing number of more wealthy people on the Earth, while maintaining high-quality soil and water resources [27]. Climate change significantly adds to this challenge by reducing the quality of soils and the availability of water in many regions through the increasing variability in temperature and rainfall [28]. The already large contribution of agriculture to global greenhouse gas emissions will increase unless more effective and climate-friendly farming systems are adopted [9].

The challenges facing agriculture are therefore three-fold: to increase production, to reduce emissions, and to adapt to a warmer and more variable climate. There is a particular need to increase agricultural productivity, reduce greenhouse gas emissions, and adapt to climate change in developing countries [29]. These challenges require an urgent and substantial increase in the focus of research, innovation, transformation of knowledge and education at all levels across all sectors related to agriculture. To do so calls for capacity building in many cases, which requires the focus not only of national and local governments, but also of international donors and the international research community. There is a further need internationally to promote the development of cropping systems and technologies that deliver highly productive systems for combined food, feed, and bioenergy production [30, 31]. Such actions require a collaborative effort across private and public research institutes and across many research disciplines.

Agricultural, food, and energy policies should be better integrated at international, regional, and local levels. They should seek to use, develop and maintain the available resources more effectively (land, soil, water, nutrients, agrochemicals, energy, genetic diversity, research capacity, information systems, infrastructure, culture) in a climate change and variability context. There is a need for flexible policies that focus on the multidimensional roles of agriculture, with priorities varying among regions depending on local resources, capabilities, and demands [9].

\section{Theme 4. Nanotechnology solutions for the future}

The application of modern nanotechnology and its contribution to ensure both energy efficiency and better utilisation of sustainable technology were covered by theme 4. One of the familiar challenges covered by the sessions was the growing political and economic pressure for an increase in the utilisation of renewable energy sources and the technological development needed to make this happen on a large scale. New sustainable energy supplies that can meet the increasing demands for energy will 
require major scientific and technological breakthroughs. Presently, one of the main challenges is to convert the maturing nano-science into nanotechnology and pave the way for a new generation of companies with a nano-technological foundation. The aim of the theme was to facilitate the link between science and industry that is crucial for the transfer of new scientific breakthroughs into commercial products. The scientific presentations focused on general principles and possible applications rather than on detailed fundamental studies. Presentations from the industry focused on research and development with less emphasis on commercial aspects.

It was pointed out in the statements made at the conference that nanotechnology will lead to the next industrial revolution, providing major new technological breakthroughs. The most urgent need is to stimulate maturation and implementation of the many new, promising nanotechnologies in developing sustainable energy technologies and improving the energy efficiency of current systems.

As clearly stated by the Fourth Assessment Report of the IPCC [9], a business-as-usual approach to research and development will not result in the fast implementation of renewable energy sources that is mandatory if society is to cope with the predicted increase in energy consumption worldwide, while simultaneously reducing emissions of greenhouse gasses from the energy sector [9]. In general, the challenge of clean energy sources involves improving renewable energy, energy efficiency, reducing the price per $\mathrm{kWh}$ produced, and increasing the scale of systems to that of large commercial systems. Nanotechnology provides new scientific and technological breakthroughs in the synthesis, characterisation, and production of new functional nano-materials with tailored properties optimised for applications within the fields of (for instance) solar energy, biofuels, fuel cells, catalysts, wind energy and hydro-energy, as well as for energy storage and improving the energy efficiency of existing systems.

The increase in the world population and the increase in GNP (not least in Asia) are expected to result in a $200 \%$ increase in world energy demand by 2050 . If this energy demand is to be supplied by increasing the use of fossil fuels alone, it will most probably lead to unacceptable and potentially catastrophic $\mathrm{CO}_{2}$ levels in the atmosphere. The development of clean energy technologies, such as solar energy, wind energy, biofuels, new energy storage systems and a new worldwide grid transmission system is therefore unavoidable [9]. Nanotechnology offers the tools needed to design and develop new functional nano-materials for sustainable energy systems to cope with increasing energy demand. Hence, investments in nanotechnology research aimed at developing new nanostructured energy materials could create immense economic and environmental benefits.

Investment in nano-science and nanotechnology is evolving rapidly, and nano-technological applications have already started to emerge at research laboratories within areas such as solar energy, biofuels, fuel cells, catalysts, wind energy, hydro energy and energy storage. However, there is a need for significant improvements with regard to efficiency, stability, scaling-up to mass production, and reductions in the cost per $\mathrm{kWh}$ produced. If clean energy systems are going to revolutionise the energy supply, the investments involved should have a commercial payback time of 5-10 years. This means that public funds must be made available in the transition period until renewable alternatives have matured to a level that ensures economic viability. Increased investments in research in and the development of new functional nano-energy materials and renewable energy technologies must be the top priority for any government wishing to address the challenges of increased energy consumption and climate change. Funding should stimulate both research and development, both at the fundamental level at research institutions and in the industry with a particular emphasis on maintaining the connection between the two. 


\section{Theme 5. Citizens and society}

Theme 5 focused in particular on how to strengthen the knowledge transfer between business, science, public policy, and administration. The discussion focused on the potentials and obstacles for the involvement and social learning of citizens in process of governance. It is well-known that the mitigation of, and adaptation to, climate change will require actions and interactions between nations, governmental and non-governmental organisations, industry in general, individual companies, and ultimately every single individual as a consumer and citizen. Understanding the complexities and mechanisms of the relationship between citizens, society and climate change is fundamental to ensure the effectiveness and efficiency of regulatory actions. This relationship involves a variety of aspects that were addressed during this theme (Table 5).

\section{Session $1 \quad$ Corporate social responsibility in an age of climate change}

Session 2 Low energy buildings and user behaviour

Session $3 \quad$ Human health and disease

Session $4 \quad$ Communication and climate change

Session $5 \quad$ Participation, learning, and socio-cultural change

\section{Table 5}

Session 1 focused on corporate social responsibility in an age of climate change. Low-energy buildings and user behaviour were the issue dealt with during session 2. Human health and disease were discussed during session 3. Communication and climate chance were discussed during session 4, and finally the focus was placed on participation, learning and socio-cultural change as important social and cultural dimensions of the climate challenges.

The discussions during Theme 5 concentrated on socio-technical systems, competence development, learning, processes of social and cultural change, communication, the corporate responsibility of enterprises, and mechanisms and tools for facilitating learning and socio-cultural changes. The statements recommended that the agreement to be adopted at the COP15 in Copenhagen should include the commitments of the Aarhus Convention as well as other incentives to support the participation and empowerment of citizens.

The legal rights of citizens to information and participation constitute a necessary precondition for addressing the challenge of climate change. The Aarhus Convention has proved that it is possible to persuade government and local authorities to commit themselves to an agreement on these rights (cf. www.unece.org/env/pp). The Convention underpins participatory rights in the context of environmental governance. It emphasises linking the public with the public authorities in a democratic context, as well as establishing a new process for public participation in the negotiation and implementation of international agreements at national level. The UNFCCC also focuses on the importance of promoting public access to information, on training scientific, technical, and managerial personnel, and on developing and implementing educational and public awareness programmes.

Furthermore, there are good examples of companies working with social corporate responsibility and from the education sector that prove that citizen participation can help to promote ownership and 
social learning, thereby guiding people's actions in meeting the challenge of climate change $[32,33$, 34].

Mass media communication also plays an important part in the task of education [35, 36]. However, in this field, there is a need to improve the public-service contribution to the involvement of citizens in deliberation, and innovative efforts to find socially robust solutions regarding the climate-change challenge.

To involve more companies, activate the whole education sector, and influence the public-service media, there is a need for both schemes and incentives. Hence, in addition to an agreement regarding legal rights to information and participation, the forthcoming global protocol on climate change should also include commitments regarding supportive schemes and incentives.

\section{Theme 6: The Arctic}

This theme covered the well-known particular vulnerability of the Arctic to climate change in terms of both ecosystems and socio-economic aspects. Extending from the Arctic Climate Impact Assessment [37], the theme pointed out changes and consequences for the Arctic following projected future changes in climate and brought together central aspects of previous themes related to a single geographical region. In contrast to the tradition of providing a kaleidoscopic presentation of causes and consequences, the focus on the Arctic provided a synthesis of an entire climate-driven 'causeeffect-consequence' spectrum involving all aspects of natural, cultural, human and socio-economic sciences.

Session 1 in the Arctic-past, present and future

Session 2 Arctic ecosystem changes and feedbacks

Session $3 \quad$ No session 3

Session 4 Use of natural resources

Session 5 Human health and socioeconomic aspects of a changing environment

Table 6

In session 1 the discussion addressed the climate of the Arctic in a past, present and future perspective in order to place the present climate development in a broader context. In session 2 the discussion focused on Arctic ecosystem changes and feedbacks. Use of natural resources was the issue discussed in session 4. Finally, human health, living conditions, and other socio-economic aspects of a changing environment were the issues discussed under session 5 (Table 6).

Studies of past climate show that the Arctic region has clearly always been subject to significant climate change and a need for adaptation. It was also stated that adaptation to fast changing conditions is essential at both cultural and ecosystem level. Indeed, an even faster level of change may be necessary for the arctic societies than for other geographical regions, because here the way of life and economy is based almost entirely on available natural resources. The Arctic is a region of extreme and rapid climate changes, significantly exceeding the global average [e.g. 9, 38,], with fragile ecosystems 
and indigenous people heavily dependent on natural resources. Its natural and traditional cultural setting is under pressure from climate change, a growing industrial interest, and enhanced exploitation of non-renewable resources. The development may promise increased wealth, but also encompasses a significant risk of degradation of ecosystems and existing social structures [9].

There are far too many examples of economic development in the Arctic in which local people have suffered a complete break-down of social structures resulting in poor health and loss of identity leading to alcoholism and abuse [9]. Therefore, the conference statements related to theme 6 recommended ensuring the sustainable development of the Arctic region in collaboration with the local communities. Participatory processes should be used in order to address the needs and concerns of local people whenever decisions are made to begin any kind of economic development in the Arctic. People in the Arctic often have traditional lifestyles such as reindeer herding, hunting, and fishing, often based on a non-monetary economy [9]. Participatory processes involve developing tools and mechanisms, which enable local people to address the inevitable social and economic changes in a world dominated by climate change.

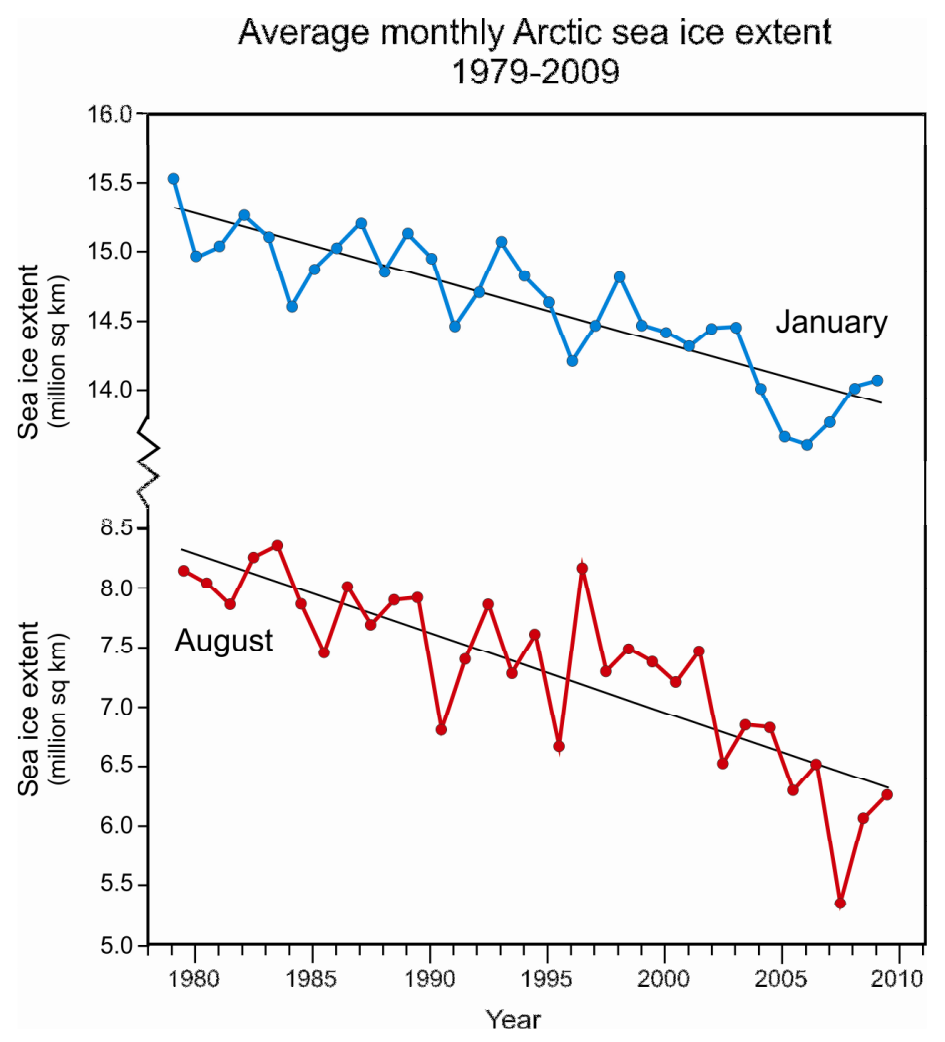

Figure 5. Theme 6 focussed on the impact of climate change in the Arctic region. One of the major changes in recent years is the decreasing extend of Northern Hemisphere sea ice. The above figure shows the changes in winter (January) and summer (August) sea-ice extend of the Northern Hemispheres from 1979-2009 [39].

Actions are needed to address these concerns and to ensure that the management of natural living resources is sustainable and based on the best available knowledge of the consequences of climate change. In many areas this depends upon the development of relevant institutions as well as research and education facilities [9].

Likewise, it is important to focus on the environmental and socio-economic impact of an increased 
extraction of non-renewable resources such as oil, gas and minerals as well as on increased shipping in vulnerable areas [9]. New technologies should be developed and environmental risk assessments as well as socio-economic studies would be needed in this process. Particularly fragile areas should be protected against non-sustainable exploitation. A particular effort should be made to understand the interaction between climate, ecosystems, natural-resource utilisation and socio-economic consequences and development. A solution could be to implement a temporary moratorium on further exploitation of non-renewable resources until these issues are resolved.

In order to improve our understanding of human impact and to distinguish it from natural climate variability, while augmenting our appreciation of non-linearity in climate effects and possible "tipping points", i.e. significant changes in ecosystems, we need an enhanced understanding of all elements constituting the climate system such as ocean currents and atmospheric conditions through the interdisciplinary study of the past climate record in order to better explain and predict present and future climate changes. In conjunction with this, we need to establish a firm understanding of how the structure and function of ecosystems react to short- and long-term changes in climate and, in particular, how resilient arctic species and, hence, the ecosystems in which they are embedded are to significant short as well as long-term changes in climate.

Partnerships between governments, scientists, industry, environmental NGOs as well as local and indigenous organisations are needed in order to identify problems and find solutions. The initiative to create these partnerships must be taken immediately after the COP15 Conference, embracing both perspectives of short- and long-term changes and consequences.

Ideally, a legally binding treaty protecting the Arctic Ocean against non-sustainable exploitation should be implemented following the agreement at COP15 in Copenhagen in December 2009.

\section{Theme 7. Integrated energy solutions}

Focus on renewable energy and energy efficient technologies were identified as the two most important areas where actions and efforts are needed in order to achieve mitigation of climate change and provide sustainable solutions for the future (Table 1)

According to the International Energy Agency (IEA), electricity generation from renewable energy sources (excluding hydro) has grown from an almost invisible $0.6 \%$ globally to close to $2.6 \%$ over the last 30 years [25]. However, in the same period, consumption has tripled, with gas and coal supplying most of the new capacity, and IEA foresees that the consumption will continue to grow for the next many years. Unless radical action is taken, fossil fuels will continue for years to be the backbone of global energy. During the last decade a wealth of new renewable energy technologies as well as energy efficiency technologies has been developed to reduce the dependence on fossil fuels, but by far the majority of the new technologies have not been implemented as part of the energy system. Consequently, the final statements of Theme 7 recommended that there is an urgent need for timely and targeted incentives for stimulating the introduction and implementation of new energy technologies.

The papers given in the meeting highlighted the following points: New energy technologies require cross-disciplinary collaboration. Integrated collaboration between biologists, biotechnologies, and engineers is especially essential. Further, the importance of the value adding effect of close collaboration with ICT expertise should not be underestimated, especially with respect to gaining and exploiting the synergy achieved by implementing integrated energy systems, embracing energy from many resources as well as incentives for introduction of energy saving instruments. 
The challenge within the area of bio-energy is to integrate into it a biomass conversion concept, so that it can contribute to the global efforts of developing alternatives to the entire spectrum of products currently obtained from oil and natural gas. Biomass conversion in biorefineries can provide not just bio-energy, but also production of biomaterials, bio-chemicals, bio-fertilizer, nutraceuticals, food and feed ingredients etc. The conceptual frame for such an integrated approach to technologies for a fossilfree society is the bio-refinery. The basic two elements in a bio-refinery are the feedstock and the agents for converting the biomass polymers into the products needed. The sustainable feed stock resources, consisting primarily of lignocellulosic materials from plant cell walls, will come from crop residues, from side streams from the agroindustry, and from municipality waste. The agents that make the biomass conversion into valuable and value added products possible are microorganisms and microbial products, primarily enzymes. With such an approach, the bio-refinery technologies can be developed without threatening the production of food and feed.

However, the most efficient short cut to energy solutions is energy savings. A series of new Danish industry initiatives have achieved a significant competitive advantage in the European and the global market by developing and commercializing energy efficient and environmentally friendly technologies, processes and products. A political action is now called for from both industry and from the research environment. Regulatory and economic instruments and clear signals that Denmark and Europe fully and wholeheartedly support the clean-tech revolution could have a strong beneficial effect. This would especially be true, if it became a central pillar for the EU policies within all four sectors: industry, agriculture, environment, and commerce. Denmark is ready to take a concrete step in implementing this vision: Danish municipalities have already very advanced plans for fossil-free solutions and energy-saving technologies and mechanisms. A central component here is the plans for $\mathrm{CO}_{2}$-neutral combined power and heat production already from 2030. The second important component is the construction of new energy-saving and energy plus houses as well as energy conscious renovation of the older houses and infrastructures.

Based on the presentations and discussions in Theme 7 it became clear that there are ample technologies, but too slow momentum in the current implementation, emphasizing an urgent need for action. As a consequence it was proposed to establish an international fund to .... and gain political support to create optimized market conditions, with clear incentives for introduction of fossil-free solutions and mechanisms for lowering greenhouse gas emissions. It is important that society establish framework conditions, which create markets that will pull the new technologies into use [9]. This will in itself stimulate investments in zero carbon emission technologies.

It was the overall recommendation from Theme 7 to establish a new global carbon tax system, which would put tax on use of fossil fuels and hereby creates incentives for use of renewable resources and energy-saving technologies and instruments. Such a global tax system could directly stimulate the development, commercialization, and use of new technologies and would furthermore aid building up a more stable momentum for the clean-tech revolution, as it would be independent of the fluctuation in oil prices. Another important advantage of an international fossil-fuel carbon tax as compared to a $\mathrm{CO}_{2}$-quota cap and trade mechanism is that it is effective as a means to ensure the polluter pays principle the profit can be used to help the developing countries. It makes it attractive for the developing countries to build their future development on renewable and/or smart clean-tech technologies. 


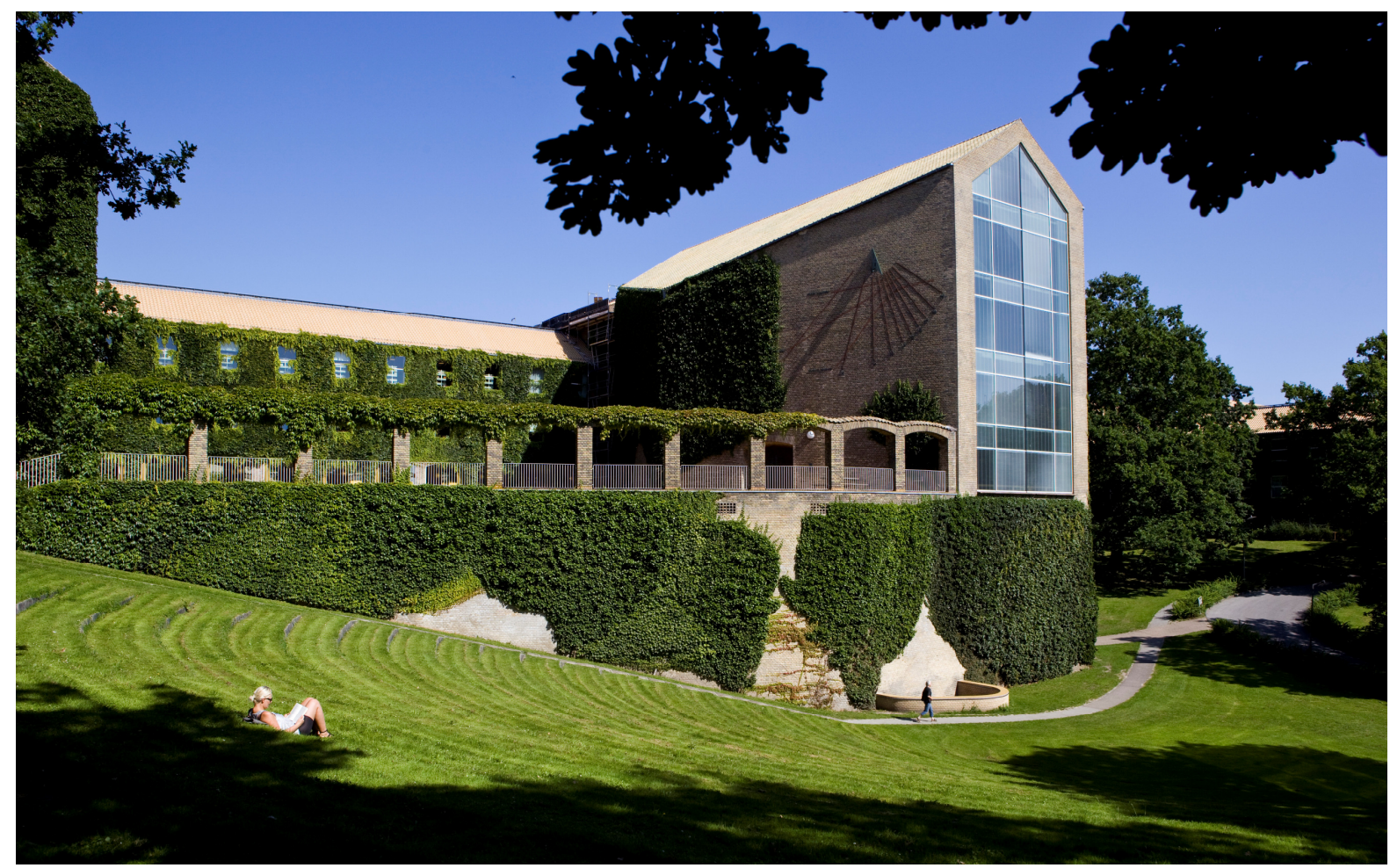

Figure 6. The Aarhus University campus. Photo: Lars Kruse/AU-photo

\section{Reference list}

[1] World Commission on Environment and Development 1987 Our Common Future Oxford University Press p 8

[2] Massai L and Montini M (eds.) 2007 The Kyoto Protocol and Beyond: Legal and Policy Challenges of Climate Change T.M.C. Asser Press

[3] Stokke O S, Hovi J and Ulfstein G (eds.) 2005 Implementing the Climate Regime. International Compliance Earthscan

[4] Depledge J 2005 The Organization of Global Negotiations. Constructing the Climate Change Regime Earthscan

[5] Lundqvist L J and Biel A (eds.) 2007 From Kyoto to the Town Hall. Making International and National Climate Policy Work at the Local Level Earthscan

[6] Sullivan R (eds.) 2008 Corporate Response to Climate Change. Achieving Emissions Reductions through Regulation, Self-Regulation and Economic Incentives Greenleaf Publishing Ltd.

[7] Schipper J, Chanson J S, Chiozza F, Cox N A, Hoffmann M, Katariya V, Lamoreux J, Rodrigues A S L, Stuart S N, Temple H J, Baillie J, Boitani L, Lacher T E, Mittermeier R A, Smith A T, Absolon D, Aguiar J M, Amori G, Bakkour N, Baldi R, Berridge R J, Bielby J, Black P A, Blanc J J, Brooks T M, Burton J A, Butynski T M, Catullo G, Chapman R, Cokeliss Z, Collen B, Conroy J, Cooke J G, da Fonseca G A B, Derocher A E, Dublin H T, Duckworth J W, Emmons L, Emslie R H, Festa-Bianchet M, Foster M, Foster S, Garshelis DL, Gates C, Gimenez-Dixon M, Gonzalez S, Gonzalez-Maya J F, Good T C, Hammerson G, Hammond P S, Happold D, Happold M, Hare J, Harris R B, Hawkins C E, Haywood M, Heaney L R, Hedges S, Helgen K M, Hilton-Taylor C, Hussain S A, Ishii N, Jefferson T A , Jenkins R K B, Johnston C H , Keith M , Kingdon J, Knox D, Kovacs K M, Langhammer P, Leus K, Lewison R, Lichtenstein G, Lowry L F, Macavoy Z, Mace G M, Mallon D P, Masi M, McKnight, M W, Medellin R A, Medici P, Mills G, Moehlman P D, Molur S, Mora A, Nowell K, Oates J F, Olech W, Oliver W R L, Oprea M, Patterson B D, 
Perrin W F, Polidoro B A, Pollock C, Powel A, Protas Y, Racey P, Ragle J, Ramani P, Rathbun G, Reeves R R, Reilly S B, Reynolds J E III, Rondinini C, Rosell-Ambal R G, Rulli M, Rylands A B, Savini S, Schank C J, Sechrest W, Self-Sullivan C, Shoemaker A, Sillero-Zubiri C, De Silva N, Smith D E, Srinivasulu C, Stephenson P J, van Strien N, Talukdar B K, Taylor B L, Timmins R, Tirira D G, Tognelli M F, Tsytsulina K, Veiga L M, Vie J C, Williamson E A, Wyatt S A, Xie Y and Young B E 2008 The status of the World's land and marine mammals: diversity, threat, and knowledge Science 322 225-230

[8] Sala O E, Chapin F S III, Armesto J J, Berlow E, Bloomfield J, Dirzo R, Huber-Sanwald E, Huenneke L F, Jackson R B, Kinzig A, Leemans R, Lodge D M, Mooney H A, Oesterheld M, Poff N L, Sykes M T, Walker B H, Walker M and Wall D H 2000 Global biodiversity scenarios for the year 2100 Science $\mathbf{2 8 7}$ 1770-1774

[9] IPCC 2007 the Fourth Assessment Report of the Intergovernmental Panel on Climate Change

[10] Hannah L, Midgley G F and Millar D 2002 Climate change-integrated conservation strategies Global Ecology and Biogeography 11 485-495

[11] Skov F and Svenning, J-C, 2004 Potential impact of climatic change on the distribution of forest herbs in Europe Ecography 27 366-380

[12] Hoegh-Guldberg O, Hughes L, McIntyre S, Lindenmayer D B, Parmesan C, Possingham H P and Thomas C D 2008 Assisted colonization and rapid climate change Science 321 345346

[13] Pacala S and Socolow R 2004 Stabilization wedges: solving the climate problem for the next 50 years with current technologies Science $305968-972$

[14] Dinkel J, Enkvist P-A, Nauclér T and Pestiaux J 2009 Pathways to a low-carbon economy. Version 2 of the global greenhouse gas abatement cost curve McKinsey \& Company

[15] Lewis S L, Lopez-Gonzalez, G, Sonké, B, Affum-Baffoe, K, Baker, T R, Ojo, L O, Phillips, O L, Reitsma, J M, White, L, Comiskey, J A, Djuikouo, M-N, Ewango, C E N, Feldpausch, T R, Hamilton, A C, Gloor, M, Hart, T, Hladik, A, Lloyd, J, Lovett, J C, Makana, J-R, Malhi, Y, Mbago, F M, Ndangalasi, H J, Peacock, J, Peh, K S H, Sheil, D, Sunderland, T, Swaine, M D, Taplin, J, Taylor, D, Thomas, S C, Votere, R and Woll, H 2009 Increasing carbon storage in intact African tropical forests Nature 457 1003-1006

[16] Luyssaert S, Schulze E-D, Börner A, Knohl A, Hessenmöller D, Law B E, Ciais P and Grace J 2008 Old-growth forests as global carbon sinks Nature 455 213-215

[17] Phillips, O L, Aragao, L E O C, Lewis, S L, Fisher, J B, Lloyd, J, López-Gónzalez, G, Malhi, Y, Monteagudo, A, Peacock, J, Quesada, C A, van der Heijden, G, Almeida, S, Amaral, I, Arroyo, L, Aymard, G, Baker, T R, Bánki, O, Blanc, L, Bonal, D, Brando, P, Chave, J, de Oliveira, A C A, Cardozo, N D, Czimczik, C I, Feldpausch, T R, Freitas, M A, Gloor, E, Higuchi, N, Jiménez, E, Lloyd, G, Meir, P, Mendoza, C, Morel, A, Neill, D A, Nepstad, D, Patiño, S, Peñuela, M C, Prieto, A, Ramirez, F, Schwarz, M, Silva, J, Silveira, M, Thomas, A S, ter Steege, H, Stropp, J, Vasquez, R, Zelazowski, P, Dávila, E A, Andelman, S, Andrade, A, Chao, K J, Erwin, T, Di Fiore, A, Euridice, H, Keeling, H, Killeen, T J, Laurance, W F, Cruz, A P, Pitman, N C A, Núñez Vargas, P, Ramírez-Angulo, H, Rudas, A, Salamão, R, Silva, N, Terborgh, J and Torres-Lezama, A 2009 Drought sensitivity of the Amazon rainforest Science 323 1344-1347

[18] Phillips OL, Lewis S L, Baker T R, Chao K-J and Higuchi N 2008 The changing Amazon forest Philosophical Transactions of the Royal Society B 363 1819-1827

[19] Dinkel J, Enkvist P-A, Nauclér T and Pestiaux 2009 Pathways to a low-carbon economy. Version 2 of the global greenhouse gas abatement cost curve McKinsey \& Company

[20] Kindermann,G., Obersteiner,M., Sohngen,B., Sathaye,J., Andrasko,K., Rametsteiner,E., Schlamadinger B Wunder S and Beach R 2008 Global cost estimates of reducing carbon emissions through avoided deforestation Proceedings of the National Academy of Sciences USA 105 10302-10307

[21] Jackson R B, Randerson J T, Canadell J G, Anderson R G, Avissar R, Baldocchi D D, Bonan G 
B, Caldeira K, Diffenbaugh N S, Field C B, Hungate B A, Jobbagy E G, Kueppers L M, Nosetto M D and Pataki D E 2008 Protecting climate with forests Environmental Research Letters 3044006.

[22] Laurance W F 2007 Have we overstated the tropical biodiversity crisis? Trends in Ecology \& Evolution 22 65-70

[23] Paterson J S, Araújo M B, Berry P M, Piper J M and Rounsevell M 2008 Mitigation, adaptation, and the threat to biodiversity Conservation Biology 22 1352-1355

[24] Smith P, Martino D, Cai Z, Gwary D, Janzen H H, Kumar P, McCarl B, Ogle S, O'Mara F, Rice C, Scholes R J, Sirotenko O, Howden M, McAllister T, Pan G, Romanenkov V, Schneider U, Towprayoon S, Wattenbach M and Smith J U 2008 Greenhouse gas mitigation in agriculture Philosophical Transactions of the Royal Society B 363 789-813

[25] IEA 2008 Energy Technology Perspectives 2008 - Scenarios and Strategies to 2050 International Energy Agency

[26] Howden S M, Soussana J F, Tubiello F N, Chhetri N, Dunlop M and Meinke H 2007 Adapting agriculture to climate change Proceedings of the National Academy of Science 104 1969119696

[27] Cassman K G, Dobermann A, Walters D T and Yang H 2003 Meeting cereal demand while protecting natural resources and improving environmental quality Annual Review of Environment and Resources 28 315-358

[28] Tubiello F N, Soussana J F and Howden S M 2007 Crop and pasture response to climate change Proceedings of the National Academy of Science 104 19686-19690

[29] Mertz O, Halsnæs K, Olesen J E and Rasmussen K 2009 Adaptation to climate change in developing countries Environmental Management 43 743-752

[30] FAO 2006 World agriculture: towards 2030/2050 Global Perspective Studies Unit FAO Rome

[31] Searchinger T, Heimlich R, Houghton R A, Dong E A, Fabiosa J, Tokgoz S, Hayes D and TunHsiang Y 2008 Use of U.S. Croplands for Biofuels Increases Greenhouse Gases Through Emissions from Land-Use Change Science 319 1238-1242

[32] Wals A E J (eds.), 2007 Social Learning - towards a sustainable world Wageningen Wageningen Academic Publichers

[33] Reid A, Nikel J, Jensen B B and Simovska V 2008 Participation and Learning - Perspectives on Education and the Environment Health and Sustainability Springer

[34] Carlsson M and Læssøe J (forthcoming 2009) Learning and participation in developmental projects directed towards sustainable development in conference centres Stevenson, Robert and Justin Dillon: Environmental Education: Learning, Culture and Agency SensePublishers

[35] Baker E C 1998 The media that citizens need U Penn Law Review 147

[36] Carvalho A 2007 Ideological cultures and media discourses on scientific knowledge Public Understanding of Science 16 223-243

[37] ACIA 2004 Impact of an Arctic Warming. Arctic Climate Impact Assessment, Cambridge University Press.

[38] AMAP 2009 Update on Selected Climate Issues of Concern. The Arctic Monitoring and Assessment Programme, Oslo

[39] The National Snow and Ice Data Center, University of Colorado Boulder, USA; ftp://sidads.colorado.edu/NOAA/DATASETS/G02135 